\title{
Modern Christian Orthodox Preacher as Social Communicator Concept
}

\section{(A tentative model of linguistic personality of a preacher in educational context)}

\author{
I.A. Petrouchko \\ Modern Languages and Intercultural Communication \\ department \\ Tver State University \\ Tver, Russian Federation \\ ivan_petrouchko@mail.ru
}

\author{
A.A. Bogatyrev \\ Theology chair \\ Tver State University \\ Tver, Russian Federation \\ bogatyria1967@gmail.com
}

\begin{abstract}
Elaboration of the modern concept of Christian Preacher communicative competences is a topical issue for Russian Orthodox Church vocational training. Meanwhile the analysis of linguistic personality as a communicator in the context of target-centered activity belongs to the domain of linguistics and communicative studies, the issues of professional communicator formation are to be treated within frame of pedagogy and linguistic didactics. The central notion of linguistic didactic is the communicator - the creator and the participant of a communicative event. So the preacher is viewed as a subject of communicative action and interaction of preaching and teaching. The present study is dedicated to mapping the competences needed to organize and perform successfully the biblical messages. The article presents the threefold linguistic personality structure of a modern Christian Orthodox preacher as a social communicator concept. The basic facet of the model comprises a set of professionally important personal qualities (such as openness, sociability, easiness of temper, consideration and discretion; readiness to accept the other; empathy, set to interpersonal communication and collaboration; personal charisma. The second facet represents a multi-tiled structure of 'know-what' competences of the Christian preacher, functioning as elements of preaching discourse production. The third facet represents a multi-tiled structure of 'know-how' competences, preconditioning the success of preaching to modern audiences. The presented model of the modern Christian Orthodox preacher as a social communicator concept maybe used as a basis for developing educational strategies, aimed at educating and training preachers in professional homiletic discourse.
\end{abstract}

Keywords-linguistic personality; communicative competence; Christian preacher

\section{INTRODUCTION}

Linguistic personality as interpersonal communication source and subject is the key notion of linguodidactics $[1,2]$. There is no doubt that genesis of Christian preacher's communicative competence is rooted in the Holy Bible and Holy Christian Church Tradition as homes of Word of God and the Christian message to humankind [3,4]. Yet the personal knowledge of key concepts of confession is not enough to disseminate the gospel to people of different personal backgrounds, beliefs and attitudes. Therefore, the key issue of philological hermeneutic and rhetorical education of the Christian preacher is centered on a listeners' response [512]. Correspondingly, the event of interpersonal communication, leading to actualization of the Word of God is the focus point for the homilist communicative competence assessment. An overview of key sources of successful preaching is provided in this article, attempting to propose a tentative model of the modern Christian Orthodox Preacher as a social communicator concept. The demand for such model is due both to real life social issues and educational needs.

\section{THE TASK}

The authors' task is to propose a succinct systematic overview on the ensemble of facets of the communicative competence model of the modern Christian Orthodox Preacher for educational purposes. It preconditions making the factions of competence visible and open to criticism from the point of view of personal background and predispositions as well as from the point of view of knowledges and skills. It also preconditions managing personal zones of proximal development in designing and fulfilling vocational training programs.

\section{THE PROBLEM}

A few words are necessary to say about the problem of modern homiletics. This problem is twofold in the modern Russian Christian Orthodox Church. It has two dimensions global and national. So let us start with global lookout first. There are numerous signs and statements of crisis of 'traditional' Christian homiletics; there are even claims that Christian sermon is dead worldwide nowadays. There are voices, claiming that preaching is a really hard job in modern, postmodern $[10,12,13-15$ etc.], post-postmodern, postindustrial, also multicultural and "multi-religious" [16], postcritical, post-Christendom [17, 18], post-Christian time and post-Christian society [19]. The society has changed. The communication standards and facilities have changed a lot. Some claim that the language barrier matters in understanding 
the Christian Orthodox sermon. And the task of the Christian Orthodox Preacher is still the same - to touch listeners' hearts and conduct biblical messages. This implies teaching the Word of God, facing the great divide between Christian and non-Christian hearts. This also implies the need for a set of personal qualities and special skills, supporting successful and effective Christian preaching in modern secular society. A preacher should try to uncover a Christian heart in the soul of modern secular or 'unchurched' man [14, p. 49].

The Western Church homiletical reflection is often focused on elaborating the opposition of so called traditional preaching and modern innovative approaches. The Russian Orthodox Church generally assumes the early Christian tradition as an ideal model to follow and the inherited Church Tradition as living evidence of Christ. Although the rhetoric of Western and Eastern Christianity may differ in many respects, the views on Early Christian Church tradition up to the eighth century as a source of development may have much in common in essence. Teaching homiletic in secular educational institutions in Russia is problematic not only because of a hundred-year gap in the preaching tradition. The academic course on 'homiletics' in Russia leaves much to be desired still in respect to understanding present day social communication culture. Since the theology chairs in universities in Russia primarily had more connections with Komsomol elites HR than with Russian Orthodox Church heritage and substantial theological education, there are still blind spots in education programs. Although copying the models of Western Church brothers may not always lead to a particular success in 'Slavia Orthodoxa' social and cultural context, their analysis of the present day tendencies and the inventive approach to preaching are worth attention. The present aim is to provide an outline of the modern Christian Orthodox preacher concept, concerning linguistic and communicative guidelines, valuable both from practical and pedagogical points of view. These have a lot to do with stipulating meta-communicative reflection of a preacher. And the authors dare say that these reflections may lay the basis of modern homiletic competences in social context formation.

\section{MATERIALS AND METHODS}

The present study is based widely on a complex phenomenological approach to drawing a professiogram of Christian preaching. It is rooted in G.I. Bogin's concept of the linguistic personality of a professional communicator as a subject of communicative interaction $[2,14,20]$. The empirical part of enquiry was performed, using a questionnaire designed to get the data, concerning hierarchy of modern audience standard expectations and aspirations in reference to the modern Christian preacher. Over 120 questionnaires were collected and analyzed as the result, reflecting priority of communicative dispositions and skills over static variables, characterizing the image of the modern Russian Orthodox Christian preacher. A high profile of desiderata and appreciation was spotted in preacher's skills of establishing contact with the audience as well as using feedback in preaching and teaching. The points of assessment, distinguished by communicative bias have been used in the Christian Preacher as elaboration of Social Communicator's Concept Model.

\section{THE PREACHER AS DESCRIPTION OF SOCIAL COMMUNICATOR's CONCEPT MODEL}

First of all, let us appreciate the assumption that outlining the concept of the Christian preacher cannot be just preachercentred, God-centred or audience-centred. The Word of God needs a lively connection between all these parts of the 'homiletical triangle'. Still the preacher is a biblical communicator, developing biblical messages to the audience of laymen. Meanwhile the interactive set in spiritual communication demands not just a passive listener, but a good layman listener, deeply involved in developing biblical messages. The dialogical approach is the pedagogical keystone in educating modern Christian Orthodox preachers for life and Christian Orthodox Church social mission.

The latter assertion contains a set of significant implications. A good preacher is to be a good conversationalist. A good preacher needs to be a good listener to make a good conversationalist [6, 19]. A good preacher must be a faithful, competent, ardent Christian and a charismatic leader in uncovering the treasures of the Word of God. As Ingunn Lunde points out, in the Christian Orthodox tradition this maybe the case of 'amplifying and varying the "original kernel"" of biblical words by the preacher [7]. So a good regular preacher must possess a talent of conducting the Word of God to listener's hearts. Preaching, of course, is a calling. And it is practice. Christian preaching is a profession and a mission in the Russian Orthodox Church. So it is important to analyse the rationale of successful preaching today, when there is a need to synthesize a good model for education of the modern Christian Orthodox Preacher as a successful social communicator and educator.

\section{THE PREACHER AS DESCRIPTION OF THE THREE-FACETED MODEL OF SOCIAL COMMUNICATOR's CONCEPT}

A series of research studies [4, etc.] has led us to a conclusion that a good sermon basis is threefold. Firstly, the success of preaching a sermon depends on the level of knowledge-based education of the Christian preacher as well as one's praying practice as a dei gratia method. This education has to do with interpretative technique, exegesis, reflection / meditation on the Holy Bible and Holy Tradition in connection to the actual present day situation and needs.

Secondly, the success of homiletic communication is vastly rooted in psychological and social personality traits of the preacher, such as openness, empathy, sincerity. These are to be polished in the moral educational program, concerned with personal image-building and communication culture acquisition tasks.

Thirdly, one of the key conditions for a successful homiletic communication is the addressee-centred text- 
production [5], i.e. rhetoric program construction, based on the balance of linguistic nomination means and communicative strategies, targeted at a specified discourse community [21]. It is the knowledge of people combined with communicative initiative and interaction skills that counts. So the elaboration of the modern Christian Orthodox preacher as a social communicator's concept, based on a multidimensional three-faceted model, is dedicated to the acquisition of homiletic communicative competency.

The Language is the ground, the milieu and the tool of understanding. It is a mirror of life. So developing the modern Christian Orthodox preacher as the social communicator's concept can serve a guiding tool for Christian education. Now let us regard the modern Christian Orthodox Preacher as the social communicator's concept based on a three-faceted model. Engaging a three-faceted model to explain the structure of linguistic personality of a communicator is not big news in linguodidactics since G.I. Bogin provided a perfect sample of such models, reflecting the ontogenetic dynamics of growth of linguistic ability and skills in a most transparent mode [1,2] the authors' 3-dimensional model. Firstly, unlike G.I. Bogin's model, the upper level of the table is not associated strongly with progress line direction. Instead of that, let us appreciate the left-to-right vector, reflecting steps and stages of discourse preparation and production. Secondly, not only adjacent factions of the model interact. Thirdly, it is a down-to-top success precondition model, presented in a top-down array.

\section{A. The basic facet-professionally important personal qualities of the preacher}

The underlying facet (or plane) comprises such traits of psychological nature, as I - openness, II - sociability, III easiness of temper, IV - consideration and discretion, V readiness to accept the other 'as is', VI - personal empathy, VII - set to interpersonal communication as a key to further collaboration, VIII - personal charisma. These features of character are usually inherited by an individual from nature. So they usually afford little dynamics, are preconditioned by culture and education, but still may be motivated (by desire to make a good preacher) and cultivated through exercise and reflection. The above-mentioned traits can be considered as professionally important personal qualities, influencing personal performance in preaching.

\section{B. The "quidditas" facet - the net of "know hat" components of the preacher's homilletic competences}

The second facet is dedicated to the concept of "know what to say'. This one "quidditas" plane has a complex and dialectical network structure, formed by a set of interdependent elements. This facet deals with concepts, sources, data, knowledge, beliefs, values and areas of assessment. It has rows (lines) of key components, presented as tiles of Table I. And it has a three-step structure, reflecting development of dialectical grades of essence. The scheme is drawn in a tentative way. It is not a language in action instances report, but rather a basic speaker's (i.e. preacher's) scheme for planning a speech. For example, let us discern certain grades of transition from such instances of thought (or rather ideas) as (1a) the immediate content of the message (a parable or another of the kind), then (1b) the pre-planned purport (the goal and the tasks of the message), as well as (1c) the ideal model of an intended communicative event, based on some biblical words (quotation), description or narrative. The 'know what' components' structure is presented in Table I. below.

The three minor facets or sub-facets, presented as indexed tiles $(1 \mathrm{a}, 1 \mathrm{~b}, 1 \mathrm{c})$ in Table I, go together well in the outline, reflecting elements of planning 'logos' for the communicative event of preaching. It may be referred, but roughly, to the renowned scheme of sermon's three targets by Jay E. Adams. That is, ' $a$. To inform. $b$. To convince (to believe or not). $c$. To motivate' [22]. But in fact they may still have little connection to an actual preaching communicative event, if other conditions for successful communication are not fulfilled.

The above-mentioned outline (1a, 1b, 1c) may be treated as just the upper side of an iceberg of preacher's experience, upon which the preaching scheme is based. There is an underlying row of sources of inspiration for the preacher. And it is dialectical and schematic. In a most skimpy manner, it can be reported as a sub-facet of preacher's Christ-centred inspirational sources - the Holy Scripture, the Holy Fathers of the Christian Church heritage and the Church Tradition, on the one side (2a) that maybe connected to the external context, and the situation of speech - on the other side (4a). Then the sub-facet of a sermon's plan (2b) and, finally, the sub-facet of pragmatics of the text, viewed as a point of accepting the meaning of the Word of God by the recipients of preacher's speech (2c). These (2a), (2b), (2c) sub-facets can and should be considered as rather naïve. Yet they retain certain hermeneutical and rhetoric value - at least in educational contexts. Needless to say that the Word of the Holy Bible functions in the sermon as a 'generator of events and interactions' [24, p. 113]. These are the basics. The successful real life application of a schoolboy's synopsis is based also on a wide range of preacher's multifarious 'know how' skills, necessary to make preaching a fruitful communicative event (to be reviewed further on).

The following two lines $(3 a-4 c)$ provide a twofold social undercurrent in support of upper two lines, concerned with the preacher's intention formation. The third row is dedicated to three elements of concern for an educated preacher. The first (3a) component of the third line is concerned with the way of life, the personal stamina and the social image of the Christian preacher. It is the 'ethos' component of preaching as a communicative act. It is not just the matter of the garment and the mean. It is the matter of personal background of spiritual insight and ethical life. It is a matter of the preacher's morality and integrity [14, p. 42]. And yes, it has a lot to do with the underlying facet (or plane) of the modern Christian Orthodox Preacher as the social communicator's concept. The second 
TABLE I. THE 'KNOW HOW' COMPONENTS' STRUCTURE

\begin{tabular}{|c|c|c|c|}
\hline $\begin{array}{c}\text { The 'know } \\
\text { what' sub- } \\
\text { facets }\end{array}$ & $\boldsymbol{a}$ & $\boldsymbol{b}$ & $\boldsymbol{c}$ \\
\hline $\begin{array}{c}\text { 1.Semantics } \\
\text { and Cognitive } \\
\text { components of } \\
\text { sermon }\end{array}$ & $\begin{array}{c}\text { The immediate } \\
\text { content }\end{array}$ & $\begin{array}{c}\text { The pre-planned } \\
\text { social } \\
\text { objectives }\end{array}$ & $\begin{array}{c}\text { The ideal } \\
\text { model of } \\
\text { intended } \\
\text { communicative } \\
\text { event }\end{array}$ \\
\hline $\begin{array}{c}\text { 2.Pragmatics of } \\
\text { sermon }\end{array}$ & $\begin{array}{c}\text { The Scriptures } \\
\text { and Church } \\
\text { Tradition. } \\
\text { sources of the } \\
\text { message }\end{array}$ & $\begin{array}{c}\text { The plan of the } \\
\text { sermon }\end{array}$ & $\begin{array}{c}\text { The Word of } \\
\text { God } \\
\text { actualization }\end{array}$ \\
\hline $\begin{array}{c}\text { 3 Conversation } \\
\text { outline }\end{array}$ & $\begin{array}{c}\text { The personal } \\
\text { background of } \\
\text { the preacher }\end{array}$ & $\begin{array}{c}\text { The planning of } \\
\text { the self- } \\
\text { representation } \\
\text { of the preacher }\end{array}$ & $\begin{array}{c}\text { Meaningful } \\
\text { communication } \\
\text { event }\end{array}$ \\
\hline $\begin{array}{c}\text { 4 Social event } \\
\text { outline }\end{array}$ & $\begin{array}{c}\text { Knowledge of } \\
\text { the target } \\
\text { audience }\end{array}$ & $\begin{array}{c}\text { Poetics } \\
\text { knowledge }\end{array}$ & $\begin{array}{c}\text { Rhetorics } \\
\text { knowledge }\end{array}$ \\
\hline
\end{tabular}

(3b) component of the third line is dedicated to planning the self-representation of the preacher in his speech, connected to the first line components, but in a special way. The third (3c) component of the third line is dedicated to the model of meaning construction in conversation. The (3b) and (3c) are connected through inversion of the medium and the message. In (3b), the preacher is a sort of a message of preaching (as a medium). In (3c), the meaning of preaching is viewed as a message, developed by the preacher and his audience as a complex medium of the message and its shared meanings.

The third and the forth row lines may be called technical (in respect to the task of substantiating the aspirations and the efforts of the preacher, reflected in the upper lines of the quidditas scheme).

The first (4a) component of the scheme is concerned with the target audience, the knowledge of its culture, language, worldview (German 'das Weltbild') and ways of life. As Graham Johnston points out, the message of God does not change, but the method of communicating should be flexible to the culture [15]. It also has to do with the context and the reason for preaching on actual social occasions. It is important, for example, on May $9^{\text {th }}$ in Russia, when every word a preacher utters is interpreted in powerful context of the day dedicated to the memory of victims of Great Patriotic war. On the other hand, there is a strong need to know and understand the sources of audience's non-commitment, a range of acceptance and rejection of the preacher's words [24]. So the presupposition of Jay E. Adams that people want 'a. To learn. b. To believe. c. To change' [22] needs sufficient justification by preaching practice.

The second (4b) component of the forth line is dedicated to things valuable both in life and educational scope. A preacher should know the basics of optimal rhetoric strategy choice (e.g. types of speech - a soliloquy, a monologue, a pedagogical dialogue speech, different genres and styles of preaching, distribution of distances, statuses, hierarchy of authorities in communication). The same is to be said about other sources and means of communicative impact, such as types of pathos, logos, ethos, intonation, etc.

Lastly, the third (4c) component is dedicated to knowledge of laws and rules of public conversation, the role of the audience commitment in the communicative event and the part the audience takes in the shared meaning construction. The preacher must understand the risks, the gives and takes of his discourse in public. The preaching is viewed here as a matter of so called 'rhetorical dynamics' $[15,24]$ and is focused on the 'pathos' of the sermon. This sub-facet implies the idea that the success of a preaching event is measured not otherwise, but by real audience's understanding and response. The latter is assessed as 'total impact' of preaching [25, p.12; 26, p.160].

To summarize, one must mention the general and bit abstract nature of the quidditas facet. It is a facet of general knowledge of the routes of the message. It is generally viewed as having certain prescriptive, but not executive power.

\section{The third facet - the net of "Know how" components of the preacher's homilletic competences}

The third and the last of the three-dimension model of the modern Christian Orthodox Preacher is a 'know-how' facet. The latter concerns knowledge and skills, needed for biblical message development. It is a "quo modo" plane of organizing the preaching event. It is also tightly connected to both other facets of the model of the modern Christian Orthodox Preacher - the dispositions and knowledge, though viewed in a rather static approach.

The third (the "quo modo") facet of the model maybe characterized by an ontological shift from static knowledge to dynamic knowledge akin to "post-linguistic" just as well as "post-semiotic" approaches in communication studies $[9 ; 28]$. The 'know-how' model investigates the practices, criticized at different angles and seen though multifarious 'communicative lenses', as G. Gerard and S.D.B. Ravasco put it [24]. It is possible to estimate the historical approach, practiced by them in investigating communication homiletic models, but the authors prefer a deductive approach. The horizontal split of the 'know-how' facet is characterized by attention firstly to contact (a), secondly to action (b), and then - to interaction between the preacher and his audience (c).

The upper line of the 'know-how' facet comprises the following three points - interpersonal contact management (5a), rhetoric action management (5b) and conversation management skills (5c) (Table II). The latter is based on a set of knowledge of various social cultural patterns, playing a role in discussion. It may be the knowledge of the best ways of anchoring the listeners' and interlocutors' attention. It may be knowledge of turn-taking strategies in discussion. It may also be the knowledge of hierarchy stereotypes, appreciated by the target audience or the knowledge of hidden rules of special 
TABLE II. THE STRUCTURE OF 'KNOW HOW' COMPONENTS

\begin{tabular}{|c|c|c|c|}
\hline $\begin{array}{c}\text { The 'know } \\
\text { how' sub- } \\
\text { facets }\end{array}$ & $\mathrm{a}$ & $\mathrm{b}$ & $\mathrm{c}$ \\
\hline $\begin{array}{c}\text { 5.Conversation } \\
\text { management } \\
\text { skills }\end{array}$ & $\begin{array}{c}\text { Interpersonal } \\
\text { contact } \\
\text { management }\end{array}$ & $\begin{array}{c}\text { Rhetoric action } \\
\text { management }\end{array}$ & $\begin{array}{c}\text { Conversation } \\
\text { management }\end{array}$ \\
\hline $\begin{array}{c}\text { 6.Situation } \\
\text { of meaning } \\
\text { construction } \\
\text { management } \\
\text { skills }\end{array}$ & $\begin{array}{c}\text { Interpreting the } \\
\text { communicative } \\
\text { situation }\end{array}$ & $\begin{array}{c}\text { Controlling and } \\
\text { transforming } \\
\text { the situation }\end{array}$ & $\begin{array}{c}\text { Re-establishing } \\
\text { the situation of } \\
\text { biblical } \\
\text { message }\end{array}$ \\
\hline $\begin{array}{c}\text { 7.Social event } \\
\text { management } \\
\text { skills }\end{array}$ & $\begin{array}{c}\text { Accepting the } \\
\text { audience }\end{array}$ & $\begin{array}{c}\text { Controlling } \\
\text { preacher's own } \\
\text { role and status }\end{array}$ & $\begin{array}{c}\text { Changing the } \\
\text { audience } \\
\text { attitude }\end{array}$ \\
\hline $\begin{array}{c}\text { 8.Psychological } \\
\text { Hermeneutics }\end{array}$ & $\begin{array}{c}\text { Understanding } \\
\text { the audience }\end{array}$ & $\begin{array}{c}\text { Assessing the } \\
\text { image of self in } \\
\text { conversation }\end{array}$ & $\begin{array}{c}\text { Assessing the } \\
\text { dynamics } \\
\text { image of the } \\
\text { recipient's } \\
\text { image }\end{array}$ \\
\hline
\end{tabular}

speech etiquette, shared by the audience. But first of all it is the realm of strategic know-how in disseminating messages among laymen and managing conversation to that end.

This row of (personal) skills $(5 \mathrm{a}, 5 \mathrm{~b}, 5 \mathrm{c})$ is substantiated by a bit more deep-rooted row of personal abilities (and skills) of a preacher as an interlocutor. So the ability to feel as well as to analyze and interpret correctly the communicative situation comes first (6a). Then the set of abilities and skills comes, needed to control and transform the communicative situation, when necessary (6b), using strategies, based on authority. The third and most precious gem of the row is the set of abilities and skills (6c), needed to construct the situation of biblical message in interaction, that is - together with the audience. This point is a 'know how' projection of 'know what' point (4c). The interactive mode of preaching is a Bible based mode. There are numerous evidences in the Holy Scripture of this mode of pedagogical conversation of our Lord Jesus Christ and the people he met. The biblical models correspond to point (1c) in the structure of Christian preacher's competence.

The seventh row line of the first point reads as the ability and disposition to accept the audience whatever it is like (7a). This skill is both of psychological and spiritual nature. It may be considered as a crucial point in preaching in a secular world. As K. Beville points out, today "the biblical communicator needs humility in communicating truth with authority $[3,50]$. The adjacent $(7 \mathrm{~b})$ point reads as preacher's ability to control the development of a communicative situation and one's own status, role and position in it. It is not just a desideratum of point (3b). There is nothing taken for granted for a preacher in an unfriendly social environment. No face-threatening communicative acts can be avoided now due to a high level of religious culture of society in secular society age. The preacher is responsible for everything that happens in the preaching communicative event. Everything is possible today, in the age of "Pussy Riot: and myriads of other social and communicative challenges". Point (7b) is not just the case of saving face of a preacher. It is also the case and precondition of saving souls of people around the preacher through conversation $(7 \mathrm{c})$.
The eighth row line is dedicated to preacher's ability of understanding. It is the hidden hermeneutic dimension of rhetoric action and interaction. So the preacher feels the audience (8a), controls the receptive side of his own 'self' image construction in discourse $(8 \mathrm{~b})$, as well as correctly interprets the image of the listener in conversation $(8 \mathrm{c})$. The latter is the objective point of communicative interaction in the preaching event. Here let us embrace the definition of preaching by H.E. Fosdick as "personal counselling on a group basis". This line of preaching practice interpretation reflects the image of the preacher as God's servant and people's servant.

There is a lot of academic disputation about postmodern sensitivity and necessity of finding new approaches in preaching. Some alarmists claim the sermon language and discourse impenetrable for audience. There are also voices heard in Russia, demanding to get rid of Church Slavonic praying as making it too hard to grasp the meaning of words and the message. There is a motivated and generally negative authoritative response to that outcry today. This negative response can be substantiated linguistically, since the general condition of secular discourse is poor and the literary norm of modern Russian is facing hard times. The negative response maybe substantiated ontologically by those who point to the fact that each type of discourse needs a special language, and the status of the speaker brings its own limitation on the language of the audience by denying acceptability of cannot be admitted in divine discourse. The Old Church Slavonic succeeds to the Greek as a Holy Scripture language and the Christian Church language. And not each and every notion of Church Slavonic can be interpreted in modern spoken Russian without unredeemable loss of biblical meaning. The Old Church Slavonic is taught as well as Scripture at parochial schools in Russia. The thesis that preaching must touch the souls of the listeners is right. And the thesis that one need not learn any new language to acquire new identity is dubious.

Nowadays the Christian preachers have to face Global process of changes in the audience under present-day conditions. There is a general shift in the audience of modern younger age people to so-called "pluralists" and "postmoderns". There are attempts to classify and analyse the actual type of recipients. Chris Altrock stated seven characteristics of "postmoderns" as those who are: "1) biblically uninformed, 2) spiritual, 3) anti-institutional, 4) pluralistic, 5) pragmatic, 6) relational, and 7) experiential" $[13 ; 12$, p.27]. There are advices and recipes on how to make such audience listen to the preacher $[13 ; 15]$. There is little wonder if the news of preaching techniques is as old as an engaging story, an image, a metaphor, questions, encounters moments likewise "Jesus primarily used to communicate the gospel" [12]. There is a good and concise overview of strengths and weaknesses, merits and demerits of the so-called traditional and new homiletics, done by Ch. M. Purdy [8, p. $198,199]$. So let there be innovative approaches and solutions, if only the preaching remains Christ-centred and leaves no soul of the listeners untouched with the Word of God. 


\section{CONCLUSION}

Generally speaking, the (a), (b), (c) approach may be interpreted as transition grades from certain precondition (a) through a certain task-solving activity (b) as another precondition to a desired result of preaching practice in interactive interpersonal dimension (c). To sum up, the preacher must know the principles and master the techniques of optimal choice of rhetoric strategies to perform dialogical interaction with the audience in developing biblical messages; the preacher must know the principles and master the techniques of achieving the desired constructive balance of the form and meaning of the sermon; the preacher must possess a know-how of achieving the constructive balance of interpretative sets with the audience.

The one-to-eight ABC-mapping of cognitive and communicative facets treated above admits applying various models of communication. It certainly can be viewed as a sort of re-interpretation of a five-step model of organizing pedagogical interaction of the preacher and the audience, proposed by A.V. Tikhomirova and A.A. Bogatyrev [20]. Yet the actual model of the modern Christian Church preacher provides more opportunities to acquire a detailed outlook on the links of the organization process of preaching practices as goal-seeking social communicative activity. It also allows one to observe the contribution of different disciplines in teaching syllabus in the professional training of modern catechists, Christian educators and clergymen.

\section{VIII.DISCUSSION}

The three-faceted multi-tiled model of the modern Christian Orthodox Preacher as a social communicator's concept, proposed here is not to be considered as flawless in any respect, but it can be appreciated as an attempt to produce an outline of preacher's readiness to preach and develop biblical messages in present day "post-religious" social environment. The factions of the model are best viewed not just as mere static points but also as playing roles in interconnections with other points of cognitive representation of the preaching strategy and the communicative event. The content of the facets can be used for educational purposes - in mapping the homiletic competences, for instance. One of the special messages that the authors' concept model has is the need for focusing practical skills in teaching and learning homiletics at theology chairs in universities. The bundle of 'knowledge that' must not substitute the set of necessary 'know-how' in preaching, organising an interpersonal event of shared biblical message meaning construction. On the other hand, the program of vocational training of the Christian Orthodox preacher and consecration may take into account the professionally important personal qualities of the candidates for 'cheirotonía' (the Greek term for ordination).

\section{References}

[1] G.I. Bogin, Typology of understanding the text, Kalinin, 1986, 87 p. (in Russian).

[2] G.I. Bogin, Modern linguodidactics, Kalinin, 1980. (in Russian).

[3] A. Men, "Bibliographical dictionary," vol. 1-3, Moscow, 2002. (in Russian).

[4] I.A. Petrouchko, "Modeling communicator personality as the basis for orthodox preacher educational training programs elaboration," Modern problems of science and education, No. 2, 2015.

[5] O. Bogatyrjova, A.Tihomirova, "Addressress of modern linguodidactic text formation and communication skills of the text", Nepreryvnoe pedagogicheskoe obrazovanie.ru. Moscow, No3, p. 138, 2013.

[6] F. de Cavel, "The Preacher as First Listener: A Grounded Theory Study in the Practice of Listening in Flemish Evangelical Preaching Tradition" / Filip de Cavel, Durham, Durham University, UK, September 2015.

[7] I. Lunde, Rhetorical Enargeia and Linguistic Pragmatics (On SpeechReporting Strategies in East Slavic Medieval Hagiography and Homiletics) ,Journal of Historical Pragmatics, vol. 5 (1), pp. 49-80, 2004.

[8] C.M. Purdy, "Evaluating the preaching in the Emerging Church in light of traditional expositional preaching: Are the homiletical model(s) in the Emerging Church different than that of the traditional expositional preaching in the Evangelical Church and are they anymore successful in addressing the need of post-modern Christians?" A Doctor of Theology dissertation. University of South Africa September 2010, 300 p.

[9] R.S. Reid, "Homiletics Dancing at the Edge of Rhetoric", Presented at the Academy of Homiletics, December 2006, pp.1-10.

[10] J. R.W. Stott, I Believe in Preaching, Hodder \& Stoughton, Religious July $1998,352 \mathrm{p}$.

[11] P. Warby, Towards a theology of interactive homiletics: an investigation of theological validity, A thesis submitted for the degree of master of theology at the South African Theological Seminary in January 2008, $177 \mathrm{p}$.

[12] D. Witherup, "A Renewed Homiletic for the Twenty-First-Century Church, 2014. Doctor of Ministry. Paper 88. - URL: http://digitalcommons.georgefox.edu/dmin/88

[13] C. Altrock. Preaching to Pluralists: How to Proclaim Christ in a Postmodern Age, MO: Chalice Press. May 2004, 160 p.

[14] K. Beville, "Preaching that Persuades", Foundations 59, May 2008, pp. $42-51$.

[15] G. Johnston, Preaching to a Postmodern World: A Guide to Reaching Twenty-first Century Listeners, MI: Baker Books. July 2001, 192 p.

[16] F. Schweitzer, "Social Constructionism and Religious Education: Towards a New Dialogue" Social Constructionism and Theology / ed. by C.A.M. Hermans...Leiden ; Boston ; Koln : Brill, 2001 (Empirical studies in theology ; vol. 7), pp. 171-185.

[17] L B. Mead, The Once and Future Church: Reinventing the Congregation for a New Mission Frontier, (Once and Future Church Series), Rowman \& Littlefield Publishers, 1991, $100 \mathrm{p}$.

[18] R.S. Reid, "Postmodernism and the Function Of the New Homileticin Post-Christendom Congregations," Homiletic, 20 (Winter 1995); pp.113.

[19] J. Paton, Preaching Christian Doctrine in a Post-Christian Society: A Dissertation presented to the Faculty of Asbury Theological Seminary,. May $2005 ; 235$.

[20] A.A.Bogatyrev, A.V.Tikhomirova, O.P. Bogatyreva. "Interactivity Levels of Paedagigic Presentation Text Formation," Mir lingvistiki i kommunikacii, vol. 1, No. 47, P. 14, 2017.

[21] C. Kramsch, Language and culture. OUP, 2009, 134 p.

[22] .E. Adams, Preaching with Purpose: the urgent task of homiletics / Jay E. Adams. Zondervan. 1998, $176 \mathrm{p}$.

[23] F. B. Craddock, Preaching. Nashville: Abingdon Press, 1985.

[24] G.Gerard, S.D.B. Ravasco, "Homiletics in the Light of the Seven plus One," East Asian Pastoral Review, vol. 49, No. 4; pp. 319-326,2012. 
[25] Long, Thomas G. The Witness of Preaching, Louisville: John Knox Press. (1989). Preaching and the Literary Forms of the Bible. Philadelphia: Fortress Press.

[26] G. Immink, "Human Discourse and the Act of Preaching" Social Constructionism and Theology, ed. by C.A.M. Hermans...Leiden ;
Boston; Koln: Brill, 2002(Empirical studies in theology, vol. 7). pp.147170.

[27] A. Leont'ev, "The tombstone of "pure" linguistics", Lingvistika na ishode XX veka, Moscow, vol. 2, pp. 307-308, 1995. 